\title{
Phosphatidylserine IgA Antibody Unit
}

National Cancer Institute

\section{Source}

National Cancer Institute. Phosphatidylserine IgA Antibody Unit. NCI Thesaurus. Code C161498.

A unit for semiquantitative measurement of IgA autoantibodies to proteins associated with phosphatidylserine evaluated ag ainst an established reference standard. 